\title{
57. DATA REPORT: DATING OF RHYOLITIC GLASS IN THE TONGA FOREARC (HOLE 841B) ${ }^{1}$
}

\author{
Ian McDougall ${ }^{2}$
}

Several samples from the rhyolitic lavas encountered in Hole 841B in the Tonga Forearc were made available by A. Ewart for potassiumargon (K-Ar) dating in an attempt to constrain the age of the eruptions.

The material was supplied in crushed form and consisted primarily of volcanic glass together with some microphenocrysts made up mainly of plagioclase and quartz. Plagioclase could not be separated in sufficient amount for dating, especially as the potassium content of the plagioclase was quite low $(\sim 0.055 \% \mathrm{~K})$. Petrographic examination of the volcanic glass indicated that it was remarkably fresh: it was clear, unaltered, and essentially isotopic. Thus, it was decided to attempt to date the volcanic glass.

Volcanic glass commonly yields unreliable $\mathrm{K}-\mathrm{Ar}$ ages because of hydration and devitrification. These processes can result in opensystem behavior for both potassium and argon in different environments, not necessarily in proportion (see McDougall and Harrison, 1988 , for a brief review). Although measured ages that are too young are often found for glasses from subaerially erupted volcanics, ages that are too old also have been encountered. Thus, K-Ar ages on glasses must be carefully evaluated and treated with caution. In the present case, the freshness of the glass and the lack of other suitable phases for dating resulted in an attempt to measure $\mathrm{K}$-Ar ages on four samples of glass from vitric rhyolitic lava Unit 2B.

A fragment size of $0.1-0.7 \mathrm{~mm}$ was used to obtain glass concentrates by standard techniques, including separations involving heavy liquids to remove the microphenocrysts. The final concentrates possessed purity values of $>96 \%$, with the balance made up of microphenocrysts within or attached to the glass.

The $\mathrm{K}-\mathrm{Ar}$ age measurements were made by flame photometry for potassium and isotope dilution for argon according to techniques previously described (McDougall and Schmincke, 1977). Argon was extracted in an ultrahigh vacuum system; subsequent to mixing with a ${ }^{38} \mathrm{Ar}$ tracer and purification, the isotopic composition of the argon was measured in a modified AEI MS10 mass spectrometer operated in the static mode. Before argon extraction at $\sim 1300^{\circ} \mathrm{C}$, the glass samples were not heated above $110^{\circ} \mathrm{C}$ in the vacuum system during bakeout.

The results of the age measurements are listed in Table 1 . As indicated, the samples of glass are from different levels in the core from the Unit $2 \mathrm{~B}$ vitric rhyolite. All samples were expected to yield

\footnotetext{
'Hawkins, J., Parson, L., Allan, J., et al., 1994. Proc. ODP, Sci. Results, 135: College Station, TX (Ocean Drilling Program).

${ }^{2}$ Research School of Earth Sciences, The Australian National University, Canberra ACT 2600, Australia.
}

essentially the same age; they were measured separately to check on the consistency of results. The apparent ages of the four samples of glass range from $42.7 \pm 0.7 \mathrm{Ma}$ to $46.5 \pm 0.5 \mathrm{Ma}$. (A considerably older apparent age was obtained on one aliquot (laboratory number 92-158), but it has not been reported here as it is thought to be aberrant, possibly because of an unverifiable laboratory error). The spread in the measured ages of about $10 \%$ is significantly greater than can be accounted for by experimental error; therefore, the ages must be interpreted with caution, emphasizing that variable potassium and/or argon loss may have occurred. Nevertheless, general concordance with a mean indicated age of $44 \pm 2$ Ma may be regarded as encouraging, perhaps to be interpreted as at least a reasonable approximation or estimation for the age of the glass and hence of the eruptive age for the rhyolite. If this age is taken at face value, then it corresponds to the Lutetian Stage of the middle Eocene, based upon the numerical time scale of Harland et al. (1990). The rhyolitic unit is overlain by upper Eocene sediments, so that the measured age is consistent with the biostratigraphic control.

\section{ACKNOWLEDGMENTS}

I thank A. Ewart for the samples and for discussion, and $\mathrm{H}$. Kokkonen and R. Maier for assistance in sample preparation and laboratory measurements.

\section{REFERENCES}

Harland, W.B., Armstrong, R.L., Cox, A.V., Craig, L.E., Smith, A.G., and Smith, D.G., 1990. A Geologic Time Scale 1989: Cambridge (Cambridge Univ. Press).

McDougall, I., and Harrison, T.M., 1988. Geochronology and Thermochronology by the ${ }^{40} \mathrm{Ar} /{ }^{39} \mathrm{Ar}$ Method. Oxford Univ. Monogr., Geol. Geophys., 9.

McDougall, I., and Schmincke, H.-U., 1977. Geochronology of Gran Canaria, Canary Islands: age of shield building volcanism and other magmatic phases. Bull. Volcanol., 40:57-77.

\footnotetext{
Abbreviations for names of organizations and publication titles in ODP reference lists follow the style given in Chemical Abstracts Service Source Index (published by American Chemical Society).
}

Date of initial receipt: 1 July 1992

Date of acceptance: 14 December 1992 Ms 135SR-140

Table 1. Potassium-argon age data on samples of glass from Hole 841B, Tonga Forearc.

\begin{tabular}{cccccc}
\hline $\begin{array}{c}\text { Laboratory } \\
\text { number }\end{array}$ & $\begin{array}{c}\text { Core, section, } \\
\text { interval }(\mathrm{cm})\end{array}$ & $\mathrm{K}(\mathrm{wt} \%)$ & $\begin{array}{c}\text { Radiogenic }{ }^{40} \mathrm{Ar} \\
\left(10^{-1} \mathrm{~mol} / \mathrm{g}\right)\end{array}$ & $\begin{array}{c}100 \mathrm{Rad} . \\
{ }^{40} \mathrm{Ar} / \mathrm{Total}{ }^{40} \mathrm{Ar}\end{array}$ & $\begin{array}{c}\text { Calculated age } \\
(\mathrm{Ma} \pm 1 \mathrm{SD})\end{array}$ \\
\hline $92-160$ & 144-841B-48R-1,5-8 & $1.157,1.155$ & 9.44 & 80.7 & $46.5 \pm 0.5$ \\
$91-259$ & 144-841B-49R-1, 10-13 & $1.158,1.183$ & 9.05 & 64.7 & $44.0 \pm 0.8$ \\
$92-159$ & 144-841B-49R-1, 15-18 & $1.319,1.345$ & 9.98 & 61.0 & $42.7 \pm 0.7$ \\
$92-158$ & 144-841B-50R-1,5-9 & $1.239,1.236$ & 9.94 & 56.0 & $43.2 \pm 0.5$ \\
\hline
\end{tabular}

Notes: $\lambda_{e}+\lambda_{e^{\prime}}=0.581 \times 10^{-10} / \mathrm{a}, \lambda_{\beta}=4.962 \times 10^{-10} / \mathrm{a}$, and ${ }^{40} \mathrm{~K} / \mathrm{K}=1.167 \times 10^{-4} \mathrm{~mol} / \mathrm{mol} . \mathrm{SD}=$ standard deviation. 